\title{
The political participation of disabled people in Europe: rights, accessibility and representation
}

Citation for published version (APA):

Waddington, L., Priestley, M., Stickings, M., Loja, E., Grammenos, S., Lawson, A., \& Fredriksdottir, B. (2016). The political participation of disabled people in Europe: rights, accessibility and representation. Electoral Studies, 42, 1-9. https://doi.org/10.1016/j.electstud.2016.01.009

Document status and date:

Published: 01/06/2016

DOI:

10.1016/j.electstud.2016.01.009

Document Version:

Publisher's PDF, also known as Version of record

Document license:

Taverne

Please check the document version of this publication:

- A submitted manuscript is the version of the article upon submission and before peer-review. There can be important differences between the submitted version and the official published version of record.

People interested in the research are advised to contact the author for the final version of the publication, or visit the DOI to the publisher's website.

- The final author version and the galley proof are versions of the publication after peer review.

- The final published version features the final layout of the paper including the volume, issue and page numbers.

Link to publication

\footnotetext{
General rights rights.

- You may freely distribute the URL identifying the publication in the public portal. please follow below link for the End User Agreement:

www.umlib.nl/taverne-license

Take down policy

If you believe that this document breaches copyright please contact us at:

repository@maastrichtuniversity.nl

providing details and we will investigate your claim.
}

Copyright and moral rights for the publications made accessible in the public portal are retained by the authors and/or other copyright owners and it is a condition of accessing publications that users recognise and abide by the legal requirements associated with these

- Users may download and print one copy of any publication from the public portal for the purpose of private study or research.

- You may not further distribute the material or use it for any profit-making activity or commercial gain

If the publication is distributed under the terms of Article $25 \mathrm{fa}$ of the Dutch Copyright Act, indicated by the "Taverne" license above, 


\title{
The political participation of disabled people in Europe: Rights, accessibility and activism
}

\author{
Mark Priestley ${ }^{\mathrm{a},{ }^{*} \text {, Martha Stickings }}{ }^{\mathrm{b}}$, Ema Loja ${ }^{\mathrm{c}}$, Stefanos Grammenos ${ }^{\mathrm{d}}$, Anna Lawson ${ }^{\mathrm{e}}$, \\ Lisa Waddington ${ }^{\mathrm{f}}$, Bjarney Fridriksdottir ${ }^{\mathrm{g}}$ \\ a School of Sociology and Social Policy, University of Leeds, LS2 9JT, UK \\ b Equality and Citizens' Rights Department, European Union Agency for Fundamental Rights, Schwarzenbergplatz 11, 1040 Vienna, Austria \\ ${ }^{c}$ Centre for Research and Intervention in Education, University of Porto, Rua Alfredo Allen, 4200-135 Porto, Portugal \\ ${ }^{\mathrm{d}}$ Centre for European Social and Economic Policy, Rue de la Pacification, 65 B-1000 Brussels, Belgium \\ e School of Law, University of Leeds, LS2 9JT, UK \\ ${ }^{\mathrm{f}}$ Faculty of Law, Maastricht University, 6200 MD Maastricht, The Netherlands \\ ${ }^{\mathrm{g}}$ Institute of Human Rights, University of Deusto, 48007 Bilbao, Spain
}

\section{A R T I C L E I N F O}

\section{Article history:}

Received 19 May 2015

Received in revised form

21 January 2016

Accepted 21 January 2016

Available online 23 January 2016

\section{Keywords:}

Disability

European Union

Human rights

Political participation

Accessibility

Social indicators

\begin{abstract}
A B S T R A C T
This paper provides the first systematic cross-national assessment of disabled people's electoral and political participation, based on research in the 28 Member States of the European Union and in the context of the United Nations Convention on the Rights of Persons with Disabilities. A mixed methods approach included policy analysis, information requests to national experts and secondary analysis of European survey data. The evidence populated indicators which suggest four lines of action: (a) lifting legal and administrative barriers; (b) raising awareness; (c) making political participation more accessible; (c) expanding participation opportunities in public life. Civil society organizations as well as public institutions have an important role to play as change agents in this regard.
\end{abstract}

() 2016 Elsevier Ltd. All rights reserved.
This paper examines the political participation of disabled people in European countries through the development of human rights indicators. In so doing, it addresses a gap in the literature with the first cross-national assessment of this topic. Political participation is considered here in broad definition-grounded in human rights, encompassing individual and collective participation in the public sphere, and located within a context of multi-scalar governance from the global to the local.

Increasing concern has been expressed by the EU institutions about low participation in European elections (TNS Opinion and Social, 2013) and the EU's first Citizenship Report sought to identify obstacles to the exercise of its citizens' rights. In so doing, it

\footnotetext{
* Corresponding author.

E-mail addresses: m.a.priestley@leeds.ac.uk (M. Priestley), Martha.STICKINGS@ fra.europa.eu (M. Stickings), emaloja@fpce.up.pt (E. Loja), cesep@skynet.be (S. Grammenos), a.m.m.lawson@leeds.ac.uk (A. Lawson), lisa.waddington@ maastrichtunversity.nl (L. Waddington), bjarnaf@hotmail.com (B. Fridriksdottir).
}

acknowledged that 'EU citizens with disabilities face additional obstacles' (European Commission, 2010a). Linking disability rights with European citizenship and political participation, the EU's European Disability Strategy 2010-2020 includes a specific commitment to 'address accessibility to voting in order to facilitate the exercise of EU citizens' electoral rights' (European Commission, 2010b). These observations hint at two dimensions to the challenge at hand-assuring equal political rights in principle and providing accessible participation processes in practice.

From a rights-based perspective, the EU and all of its 28 Member States have signed the United Nations Convention on the Rights of Persons with Disabilities (CRPD), and all but three have now ratified it. This treaty provides a global frame of reference and legally binding obligations concerning civil, political, social, economic and cultural rights. In particular, Article 29 obliges state Parties to ensure equal rights to participate in public and political life, including: engagement in non-governmental organizations and associations; joining political parties; free and accessible voting procedures, facilities and materials; standing for election and 
holding public office at all levels.

At the European level, Article 20 of the Treaty on the Functioning of the European Union (TFEU) affirms that all nationals of an EU Member State also acquire citizenship of the Union. This includes the right to vote or stand for election in European and municipal elections while living in another EU Member State, on an equal basis with nationals of that state. Chapter V of the accompanying Charter of Fundamental Rights of the European Union also declares that 'everyone is equal before the law' and that 'any discrimination' on grounds of disability is prohibited, as it is on grounds such as gender or racial discrimination too (Articles 20 and 21).

In this way both the global human rights framework of the CRPD and the regional integration structures of the EU convey to disabled people 'post-national' citizenship rights that exemplify wider processes of multi-scalar governance. As Bhabha (1999) argues, '....it is the interface between globalization and human rights that challenges state autonomy most forcefully...' Nevertheless, electoral and political process remain largely within the national competence of individual EU Member States so it is important to understand the realization of disabled people's political rights within each country while taking a comparative view in the frame of European and global treaty obligations.

\section{Disability: a missing socio-economic variable?}

Political participation gaps for other social groups have been shown often, notably in relation to gender inequalities (Baum and Espírito-Santo, 2007; Jennings, 1983; Morales, 1999) or ethnicity (Kasfir, 1970; Leighley and Vedlitz, 1999; Wrinkle et al., 1996) while Gallego (2007), for example, examined the multiplicity of gender, age, social class, education, income, ethnicity, and work status effects in 24 European countries. We know that political participation resources are 'distributed differentially among groups defined by socioeconomic status' (Brady et al., 1995) and that inequality within European countries 'magnifies the relationship between income and participation' (Lancee and Van de Werfhorst, 2012).

Despite compelling evidence that disabled people experience systematically higher risks of household poverty and social exclusion in terms of employment, education, relative income and material deprivation (Grammenos, 2013a) such comparative studies have not included disability status as a variable. Hence, there is a strong case that disability equality should be considered along with other socio-economic variables when researching political participation, but there are unique dimensions to consider too. For example, we know that voting opportunities in general make a difference to turnout in European Parliamentary elections (Mattila, 2003) but in the case of disability we need to consider both 'access to' and the 'accessibility of political activities for people with impairments (e.g. for wheelchair users, blind people, deaf people, people with cognitive impairments, etc.).

There have been some pioneering national electoral studies that do consider disability in this way, notably in the USA (Shields et al., 1998a,b). Such researchers found voter turnout to be lower amongst disabled people than non-disabled people, and more so amongst those who were older, poorer or with significant mobility impairments (Schur et al., 2002). Despite prominent nondiscrimination legislation these gaps have remained large, 'possibly due to the combined and interactive effects of polling place inaccessibility, social isolation, fewer economic resources, and perceptions that the political system is unresponsive' (Schur and Adya, 2013).

Such findings led also to the conclusion that 'the political involvement of people with disabilities may greatly depend on the extent to which political elites attempt to address their political concerns' (Shields et al., 1998b) and 'indicating that outreach policies of disability organizations can play a large role in creating conditions that encourage political participation' (Schur, 1998). Subsequent research in the UK drew attention to the specific barriers facing people with intellectual impairments and the importance of social capital and networks of support as enablers of political participation (Bell et al., 2001; Keeley et al., 2008; Redley, 2008). These findings suggest that establishing political rights and providing accessibility may not be sufficient to achieve full participation without also engaging proactively with disabled people in civil society and with their political claims.

Relevant to this, Reudin's (2007) elaboration of Milbrath's (1965, 1981) seminal hierarchy of political participation showed empirically how 'both political institutions and social capital are significant contributors'. Indeed, social capital, community 'roots' and connectedness can all boost engagement in political activity (Anderson, 2010; Bandura, 1997, 2000; Caprara et al., 2009; Yeich and Levine, 1994) and, as Iris Marion Young has argued:

We deepen democracy when we encourage the flourishing of associations that people form according to whatever interests, opinions, and perspectives they find important. Strong, autonomous, and plural activities of civic associations offer individuals and social groups maximum opportunity in their own diversity to be represented in public life. (Young, 2002, p. 153)

Civil society organizations foster new forms of political participation (Dalton et al., 2004; Zakaria, 2007) and the rise of the disabled people's movement is no exception. Its mobilization and activism has placed disability rights on the political agenda and secured significant legislative gains-not least through the UN CRPD. It has evolved alternatives to traditional political engagement, created new forms of social capital, and developed new opportunity structures to influence publics, politicians and governments (Driedger, 1989; Fleischer and Zames, 2001; McNeese, 2013; Oliver and Barnes, 2012; Pfeiffer, 1993; Scotch, 1988; Shakespeare, 1993).

The European voices of this global movement are evident in relation to the concerns of this paper. For example, the European Disability Forum (EDF), which represents the collective voice of 80 million disabled people to the EU institutions, organized a 'Disability Votes Count' campaign in 2009 and, in the run-up to the 2014 European Parliament elections, disability platforms or manifestos were published by pan-European civil society organizations of disabled people including EDF, the European Union of the Deaf (EUD), and the European Blind Union (EBU).

As shown so far, there is a firm basis on which to seek full and equal political participation in Europe. Disabled people should be regarded as a significant socio-economic group whose political participation outcomes may be contingent on the transnational governance of basic citizenship rights, on the accessibility of mainstream political activities and on political engagement with their collective concerns in civil society.

Previous socio-economic variable studies have also demonstrated the potential to conduct political participation research comparatively in the EU context. As a starting point, in 2010, the European Union Agency for Fundamental Rights (FRA) published a preliminary legal study on The right to political participation of persons with mental health problems and persons with intellectual disabilities followed by a report on legal capacity issues (European Union Agency for Fundamental Rights, 2010, 2013). These two reports suggested that, while some progress had been made in some EU Member States, much remained to be done even on basic rights. The 2014 European Parliamentary elections offered an opportunity to examine these issues. The present research was launched in this 
context to indicate the bigger picture of electoral and political participation rights for all disabled people in Europe.

\section{Methods}

The objective of the research was to develop a new set of comparative indicators on disabled people's participation in public and political life across the EU Member States. This initial work was carried out in 2013-4. The approach was based on the United Nations' typology of human rights indicators, which is based on 'structure', 'process' and 'outcome' (Office of the High Commissioner for Human Rights, 2006, 2008, 2012). These dimensions broadly correspond to Landman's (2004) distinction between thinking about human rights in 'principle', 'policy' and 'practice'. Within the UN framework, 'structural' indicators refer to 'the ratification and adoption of legal instruments and existence of basic institutional mechanisms'. 'Process' indicators evidence the efforts that states are making to implement these commitments (e.g. the kinds of strategies, programmes and investments they have put in place). 'Outcome' indicators then seek to 'capture attainments ... that reflect the status of realization'-primarily the outcomes for those whose rights should be protected (Office of the High Commissioner for Human Rights, 2012).

In the disability field, a rather similar model had been proposed, using a typology of 'rights, access and participation' (Lawson and Priestley, 2009, 2013). In this version, the specific legal obligations enshrined in the text of the CRPD would be translated into indicators of rights in law, of the accessibility of public environments, goods and services, and of participation outcomes for disabled people. A range of disability equality indicators were developed to pilot these proposals under the auspices of the Academic Network of European Disability experts (ANED) from 2009. In this paper we combine the OHCHR and ANED typologies to interpret 'structure' as disability equality in law, 'process' as investments in better access for disabled people, and 'outcomes' as measurements of participation and accessibility.

At the same time, the European Union Agency for Fundamental Rights (FRA) was developing indicator methodologies within its areas of remit, including children's rights (European Union Agency for Fundamental Rights, 2011; Stalford et al., 2009). Following the EU's accession to the CRPD at the end of 2010 a formal monitoring framework for disability rights was established under Article 33(2) of that Convention, including the FRA, the European Commission, the European Ombudsman, the European Parliament and the European Disability Forum (representing the voice of disabled people in civil society). Both ANED and FRA proposed new research on political participation in their annual work programmes to coincide with the 2014 European Parliamentary elections and the Disability Unit of the European Commission's invited a collaborative venture between them.

An initial table of 47 possible indicators was drawn up by adapting items from the ANED proposals into the UN typology and adding new items from a scoping of European data sources. It included, for example, indicators of legal rights to vote or stand for office (structure), awareness raising programmes for election officials or guidelines on accessible polling stations (process), and the participation rates of disabled people in various types of political activity (outcomes). This outline was presented to the EU's Disability High Level Group of states' representatives in 2013, refined in discussion with the European Commission's Disability Unit and populated with both quantitative and qualitative forms of evidence.

To gather qualitative data, structured reporting requests were made to national experts from the standing networks of the two main research partners-FRANET (FRA's multidisciplinary research network), which focuses on all fundamental rights, and ANED, which focuses on disability issues. In this way, we were able to coordinate the collective effort of more than 50 researchers in 28 countries to produce country reports relating to a wide range of topics.

To populate the quantitative indicators we examined microdata from five European surveys, summarised in Table 1.

Each survey offered a 'disability' proxy variable, typically asking whether a person has a long-lasting impairment or health condition and asking if they experience any limitations in everyday activities (for example, Q43 in EU-SILC asks, 'Do you have any chronic (long-standing) physical or mental health problem, illness or disability?' and Q44 asks, 'Are you limited in your daily activities by this physical or mental health problem, illness or disability?'). Whilst there are disagreements about the phrasing of such questions in social surveys, and the cross-cultural reliability of selfreported prevalence, this remains the established approach for comparative disability estimations (Abberley, 1992; Altman and Barnartt, 2006; Grönvik, 2009; Madans et al., 2011; Zola, 1993) and it is consistent with Eurostat's statistical disaggregation of EU disability data. These type of functional limitation/impairment variables were used as a proxy to cross-tabulate 'disability' status with a range of political participation items in each survey, in a similar way to participation studies on other socio-economic variables (e.g. those on gender, ethnicity or age noted earlier in the paper). Comparative weighted output tables were produced by country and for the EU as a whole.

The evidence collected by the ANED network was reviewed by senior team members who drafted summary thematic reports (e.g. Grammenos, 2013b; Lawson, 2014; Waddington, 2014). These, and the evidence collected by the FRANET were reviewed by FRA staff, who then developed a combined compendium report. This was discussed with a peer review group of independent experts and an initial report was published to coincide with the 2014 European Parliamentary elections.

A summary was translated into the 22 official languages of the EU Member States and a structured presentation of 27 indicators was developed on the FRA website with supplementary infographics and a series of briefing papers communicating key messages to stakeholders (for more details see, European Union Agency for Fundamental Rights, 2014).

We present first a summary of the findings, contextualised in relation to the indicator typology, before discussing them under four themes that emerged from the compendium analysis. This analytical framework is represented in the matrix of themes and indicator types shown in Table 2.

\section{Findings}

\subsection{Structure: establishing an equal right to participate}

Our typology presents 'structural' indicators as evidence of established legal rights but the transnational context outlined earlier includes legal instruments at different levels of a multiscalar governance framework-global (UN), European (EU) and national. The interactions between these add complexity but, to begin at the global level, we can first ask about commitments to the CRPD and its most relevant Articles. Following the concepts advanced from the literature, the provisions of Article 29 CRPD on 'Participation in political and public life' are clearly relevant but also Article 12 on 'Equal recognition before the law' (including legal capacity) and Article 9 on 'Accessibility' (including public buildings and communication technologies).

At the time of the research, all of the EU Member States except Finland, Ireland and the Netherlands had ratified the CRPD and only 
Table 1

Sources of survey microdata.

\begin{tabular}{|c|c|c|}
\hline Survey & Dataset & Notes and acknowledgements \\
\hline $\begin{array}{l}\text { The European Union Statistics } \\
\text { on Income and Living } \\
\text { Condition (EU-SILC) }\end{array}$ & $\begin{array}{l}\text { A } 2006 \text { ad-hoc module covered 'Social participation' with } \\
\text { data from } 366,258 \text { people aged } 16 \text { or older in private } \\
\text { households. }\end{array}$ & $\begin{array}{l}\text { SILC is the EU's reference source for comparative statistics on income } \\
\text { distribution and social exclusion (Eurostat, 2010). }\end{array}$ \\
\hline $\begin{array}{l}\text { Eurostat's Flash Eurobarometer } \\
345 \text { on 'Accessibility' }\end{array}$ & $\begin{array}{l}\text { Data from telephone interviews with 25,516 people aged } 15 \\
\text { and over in } 27 \text { EU Member States. }\end{array}$ & A targeted survey on the issue of accessibility \\
\hline $\begin{array}{l}\text { The European Social Survey } \\
\text { (ESS) }\end{array}$ & $\begin{array}{l}\text { The January } 2012 \text { microdata edition included } 46,257 \text { people } \\
\text { in } 24 \text { countries ( } 18 \text { EU Member States, data for Hungary was } \\
\text { provisional). }\end{array}$ & $\begin{array}{l}\text { Measures public attitudes, beliefs and behaviour patterns } \\
\text { European Social Survey (2014); European Social Survey Round } 6 \text { Data } \\
\text { (2012). }\end{array}$ \\
\hline $\begin{array}{l}\text { The European Quality of Life } \\
\text { Survey (EQLS) }\end{array}$ & $\begin{array}{l}\text { The third wave in } 2011-12 \text { surveyed } 43,636 \text { people in } 34 \\
\text { countries, including } 27 \text { EU Member States }\end{array}$ & $\begin{array}{l}\text { Covers a range of issues, such as employment, income, education, housing, } \\
\text { family, health and work-life balance, as well as subjective measures of } \\
\text { happiness, life satisfaction and societal quality (GfK EU3C, 2014). }\end{array}$ \\
\hline $\begin{array}{l}\text { The Survey of Health, Ageing } \\
\text { and Retirement in Europe } \\
\text { (SHARE) }\end{array}$ & $\begin{array}{l}\text { Covers } 19 \text { European countries and the } 2011 \text { dataset } \\
\text { (Release } 1.1 .1 \text { of Wave } 4 \text { ) contained } 58,489 \text { observations }\end{array}$ & $\begin{array}{l}\text { A survey of older people's life conditions, views and experiences (Börsch- } \\
\text { Supan et al., 2013a, 2013b; Malter and Börsch-Supan, 2013) }\end{array}$ \\
\hline
\end{tabular}

Malta had entered any reservation to Article 29-simply that it reserved 'the right to continue to apply its current electoral legislation in so far as voting procedures, facilities and materials are concerned' and 'to apply its current electoral legislation in so far as assistance in voting procedures is concerned' (United Nations Treaty Collection 2014). As a basic type of 'structural' indicator, concerning rights in law, ratification of the UN Convention raised few immediate issues. Formal progress has been made by almost all EU Member States, demonstrating their broad commitment in principle. Nevertheless, the devil is in the detail and concerns were soon raised on the questions of legal capacity and accessibility suggested by earlier national studies.

The denial of disabled people's voting rights has drawn past attention, notably in the denial of rights to people with intellectual or psychosocial impairments perceived to affect their mental capacity. In the USA, Schriner et al. (1997) encapsulated this challenge as 'the last suffrage movement' (see also, Karlawish et al., 2004; Schriner and Batavia, 2001; Waterstone, 2003). With regard to legal capacity, only three countries (Estonia, France and Poland) had entered any legal declaration against Article 12 CRPD but many still deprived people of their legal capacity to vote or to stand for election in national legislation. Indeed, only seven out of the $28 \mathrm{EU}$ Member States (Austria, Croatia, Italy, Latvia, the Netherlands, Sweden and the United Kingdom) explicitly guaranteed equal voting rights for all, including those without legal capacity. In the remainder, certain categories of disabled people were denied rights either constitutionally, in electoral legislation or via the discretion of a judge or medical practitioner. In $18 \mathrm{EU}$ Member States, disabled people deprived of legal capacity also had no direct access to redress if their voting rights were infringed. For example, in Denmark, Estonia, Greece, Ireland, Lithuania, Poland and Slovakia, a person would first have to challenge the decision on their legal capacity in order to then seek redress for deprivation of their right to vote.

Article 9 CRPD (on Accessibility) highlights states' obligations towards the removal of barriers in built environments, transport and information and communications and this was a priority theme also at the EU level in framing the European Disability
Strategy 2010-2020. None of the EU Member States ratifying the CRPD had entered any reservation against this Article, accepting their obligations in full. This has clear implications for their efforts to ensure political participation for disabled people, such as the accessibility of polling stations, voting machines, media and internet communications, campaign material, public meetings or the training of election officials. For example, access to mass media communications is vital to informed political knowledge but in only half (14) of the EU Member States were both public and private broadcast providers subject to statutory accessibility standards to provide subtitles, sign language interpretation and/or audio descriptions for all or part of their programming.

Access to voting for people living in long-term institutions is regulated by specific laws in at least 18 EU Member States but takes various forms. For example, polling stations may be set up at some residential institutions in Austria, Bulgaria, Finland, France, Germany, Italy and Poland. In Hungary, Latvia, Lithuania, Slovenia and Slovakia, individual advance application is required from a voter for such a polling station. In Romania a mobile ballot box may be provided for national elections on request to the president of the district election bureau with medical proof that a person cannot be transported to a polling station. Mobile polling stations are not provided in this way in Denmark, Spain, the Netherlands, Romania, Sweden or the United Kingdom, where provisions for institutional residents tend to be covered by generic measures on alternative voting (such as postal or proxy voting). In most cases a voter would need to request such adjustment well in advance of polling day. No legislation specifying adjustments for people living in long-term institutions were identified in Belgium, Cyprus, Greece or Luxembourg, although rates of institutionalisation are relatively high in some of those countries (see also, O'sullivan, 2001 on policies and practices affecting voting for people living in American nursing homes).

The preceding examples show how 'structural' human rights indicators can reveal legal and administrative barriers to political participation (the top left cell in our matrix). Other structural items indicated a need to raise awareness, to make political participation

Table 2

Analytical themes and indicators of disability rights.

\begin{tabular}{|c|c|c|c|}
\hline Indicator type & 'Structure' & ‘Process’ & ‘Outcomes’ \\
\hline Analytical theme & Establishing legal commitments & Investing in access(ibility) & Reducing inequalities; increasing participation \\
\hline $\begin{array}{l}\text { Removing legal and administrative barriers } \\
\text { Raising rights awareness } \\
\text { Making political participation more accessible } \\
\text { Expanding opportunities for political participation }\end{array}$ & & & \\
\hline
\end{tabular}


more accessible and to expand opportunities for disabled people. To underline the key finding then, the EU and its Member States have aligned strongly with the global governance framework of the CRPD and with a European framework of fundamental rights. They have undertaken to ensure that disabled people "can effectively and fully participate in political and public life on an equal basis with others' (Article 29), but in many EU Member States that equality is denied to some groups of disabled people in the structure of national laws.

In this way, populating even the most basic of structural indicators revealed new and important comparative knowledge about disabled people's political rights in Europe-and in a way that could be easily conveyed to policy makers. Whilst there will always be difficulties of comparability between different national legal instruments, these kinds of structural indicators proved relatively easy to populate by drawing on networks of national policy experts and formed the largest group in the indicator matrix.

\subsection{Process: efforts to secure political participation rights in practice}

The second type of indicator relied on evidence of 'process', in the efforts by EU Member States to facilitate the political participation of disabled people beyond formal rights on paper. For example, what programmes and investments have been initiated? A total of 12 indicators were grouped under this heading (the middle column in the matrix). The problematic of multi-scalar governance is evident here too with global, European, national and sub-national dimensions to consider. The following examples illustrate this.

One symbolic approach to indicators of investment in access, applied in other studies, is to sample key government websites for their accessibility to disabled people (Goodwin et al., 2011). This can be applied similarly to public websites of relevance to political participation. For example, in at least six EU Member States (the Czech Republic, Lithuania, Malta, Poland, Spain and Sweden) the website providing information on how to complain about infringement of voting rights met internationally accepted web accessibility standards (the WCAG 2.0 AA standards). In Finland, the Parliamentary Ombudsman's website provided information on redress in Sign Language, as did the Chancellor of Justice's website. In most countries important web-based information was only partially accessible. For instructions on voting and information on candidates, in only 10 countries was it possible to confirm that the main website of the ministry responsible for organizing elections met the standard, although in a further 12 countries some accessibility measures had been implemented (in the compendium report the latter finding was reported as an 'outcome' but here we present it as a 'process' investment).

With a view to the 2014 European and municipal elections the indicators prioritised efforts to make voting more accessible. With the exception of Croatia, no specific legal requirement could be identified for training election authorities or officials in disability rights, accessibility and reasonable adjustment. Nevertheless, examples of such training were identified in at least nine EU Member States (Belgium, Cyprus, Finland, France, Italy, Lithuania, Poland, Spain and the United Kingdom).

Evidence of efforts to make regular polling stations more accessible to disabled voters was also sought and national guidance was identified in over half (17) of EU Member States. Sometimes this was issued directly by government (as in Belgium, Denmark or the Netherlands). In Denmark, for example, guidance to municipal election authorities included a requirement that within each polling station there should be at least one voting booth with room for three people (where election officials or personal assistants might help someone to vote).

In other countries, guidance was issued by election authorities or by national human rights bodies but NGOs also played a role in promoting accessibility. For example, the Portuguese National Electoral Commission issued guidance to municipal election authorities on the accessibility of polling stations only after a complaint by a national disability organization. In Latvia, collaboration between the Central Elections Commission and two NGOs resulted in the publication of booklet guides to accessibility and non-discrimination. This kind of engagement from civil society organizations is a theme to which we return later.

Formal complaints concerning the right to political participation of disabled people were rare, with few cases considered by the courts or other bodies. In the period 2000 to 2013 only one such case was heard by the European Court of Human Rights (ECtHR), in Alajos Kiss v. Hungary. A total of 12 national court cases were identified in eight Member States. Five concerned people deprived of their legal capacity and seven concerned aspects of access to voting. In the same period, a further 13 non-judicial redress cases were identified in $10 \mathrm{EU}$ Member States, five cases related to the accessibility of polling stations and four to the participation rights of people with visual and hearing impairments. There was evidence that human rights bodies in five countries had issued recommendations on the political participation of disabled people. In the majority, however, no relevant cases had been reported by either judicial or non-judicial mechanisms.

Our study also sought evidence of efforts by political parties. Parties in the EU operate independently of the state, neither are they subject directly to the global disability governance framework, but States do have obligations under Article 29 CRPD 'to promote actively an environment in which persons with disabilities can effectively and fully participate in the conduct of public affairs [ ... ] on an equal basis with others'. At the European level, the EU also has some influence and in September 2014 it adopted new rules on European political parties and political foundations. In order to register statutes with the European Parliament, a political alliance now 'must observe, in particular in its programme and in its activities, and through those of its members, the values on which the European Union is founded, namely respect for human dignity, freedom, democracy, equality, the rule of law and respect for human rights' (see annex to European Parliament and European Council, 2014). By implication this includes the human rights of disabled people as assured in EU Treaty and by the EU's conclusion of the CRPD.

The 13 parties identified in the official European Parliament list of grants to political parties were contacted to ask whether their manifesto, charter, website and information on candidates would be provided in accessible formats; eight responded. Preparation of 2014 campaign material was still ongoing at the time but the analysis suggested that commitments by the Euro-parties to provide information in accessible formats had been rather influenced by the political claims of disabled people's organizations. Notably, in June 2013, a meeting between the European Disability Forum and the leaders of the political groups in the European Parliament resulted in a declaration in which the European People's Party, Socialists \& Democrats, Alliance of Liberals and Democrats for Europe, Greens/European Free Alliance and the Confederal Group of the European United Left/Nordic Green Left groups all pledged to 'make every effort to ensure the accessibility of their documents and information, with particular emphasis on our websites' (Confederal Group of the European United Left/Nordic Green Left, 2013). Similarly, the European Union of the Deaf organised a campaign in November 2013 for more accessible political party websites for deaf people and 32 MEPs from five Parliamentary groups signed their manifesto. 
This, together with the theoretical observations framing this paper, underlines the importance of the new social capital and collective agency arising within the disability movement. It was therefore important to consider the extent to which disabled people's organizations (DPOs) were being engaged in political process. Opportunity structures for DPO involvement in public policy development had been legally established in 13 of EU Member States with facilitated mechanisms for consultation, such as representation on a national disability council or policy forum (as in Belgium, Bulgaria, Croatia, the Czech Republic, Denmark, Estonia, Latvia, Luxembourg or the United Kingdom).

The above examples illustrate a range of process indicators. Overall, these were more difficult to populate reliably than structural indicators. They relied heavily on the identification by national experts of implementation examples or on responses by key stakeholders to information requests. Such enquiries were very helpful in identifying case studies of promising practice but they were less likely to provide certainty about the absence of such practices in other countries. Nevertheless, where an existing programme or investment could not be found through the focused enquiry of national experts it is rather likely that its dissemination and impact on practice will be also rather weak. For indicative purposes at least, indicators of process proved a useful element in the comparative assessment of political participation.

\subsection{Outcomes: where is the evidence of achievement?}

Moving to the final type of indicator, the research sought comparative evidence of outcomes (the third column in the matrix). In studies of other socio-economic variables, such as gender studies noted earlier, European survey data has provided a good starting point for participation outcome indicators. This approach was tested for feasibility in the case of disability, using statistical and econometric tests. Information requests were also made concerning the presence of disabled people as elected representatives. However, one of the key points raised in Lawson and Priestley's (2009, 2013) typology for disability rights indicators is the need to look beyond individual outcomes and to consider change outcomes in the environment too (i.e. to seek measurements of accessibility as well as participation). The following examples illustrate the range.

Data about elected representatives has been often used to indicate gender inequalities (albeit in male-female binaries). There is no public source of information on the disability status of Members of the European Parliament so it was necessary to rely on research enquiries. Members of Parliament declaring a disability status were identified in seven EU Member States. Amongst these, Croatia reported the greatest number (seven) followed by Poland and the United Kingdom (with three each). The Greek national Parliament had received two requests from members for accommodation due to disability since 1996, while information from the Portuguese parliament indicated that one member claimed a disability-related income tax allowance. In Cyprus and Luxembourg official data suggested that no members identified as disabled. In six other countries examples of parliamentarians were found from unofficial sources that identified a disability status (e.g. candidates' web pages or media coverage) but in the remaining 13 Member States no data could be found.

Only in Croatia, Greece and the United Kingdom was public data available concerning local government representatives (some unofficial data was available in Austria and Sweden). The most comprehensive data was from the UK, where a census of local authority councillors was conducted by the Local Government Association in 2010 indicating that $14 \%$ of local councillors reported a long-term illness, health condition or disability that limited their daily activities or the work they could do (an older than average age profile of local councillors should be noted here). Clearly there are some ethical considerations in the privacy of such data but the absence of systematic equal opportunities monitoring on grounds of disability across European, national and municipal assemblies raises questions and is a finding in itself.

Turning to indicative findings from the survey data, disability status and severity of impairment are associated with variation in typical measures of political participation (such as trust, political activity, etc.) but age and gender effects mask this. In addition, wide variation in the prevalence of self-reported impairment between European countries, particularly amongst older people, makes it difficult to report precise comparative measurements of participation (Grammenos, 2013b). Here we report aggregate measures at the European level to indicate the difference that disability makes to participation outcomes.

While disabled people appear to be more interested in politics than non-disabled people (51\% compared to $47 \%$ in the ESS data) this is affected by their older population age profile and there was no systematic association when comparing age-similar groups. People who report an impairment also report lower satisfaction 'with the way democracy works' in their country (5.3) compared to people who do not (5.4), on a ten-point scale. The difference is small but significant at the $5 \%$ level.

Applying an econometric analysis, we divided the scores into 'dissatisfied' (0-4) and 'satisfied' (6-10) and controlled for age, education, economic status, poverty risk, origin and household structure. In the sample, $61 \%$ were 'satisfied' but severe impairment decreased the probability of being so by 11.5 percentage points when compared to people reporting no impairment (moderate impairment decreased the probability by 4.7 points). Disabled women reported lower satisfaction than men and satisfaction tended to increase with age (although in former Eastern Bloc transition states like Estonia, Poland and the Czech Republic this was not the case). Scandinavian countries, often considered more egalitarian, and with well-developed social protection systems (Finland, Sweden and Denmark), were associated with higher levels of satisfaction overall.

Data from the EQLS survey indicated a strong impact of the degree of impairment on trust in parliament and government. For the 28 EU Member States the average trust in parliament score amongst people reporting severe impairment was 3.7, compared to 4.0 for people with a moderate impairment and 4.1 for those reporting no impairment (the results for trust in government were similar at 3.7, 3.9 and 4.0). The differences for trust in local government authorities were insignificant, despite the fact that these authorities are mainly responsible for arranging services for people with severe impairments in European welfare states. Applying econometric analysis based on the binary variable of an 'unfavourable' score (1-5) or 'favourable' score (6-10), the percentages of favourable scores in the sample were $29 \%$ for the parliament, $28 \%$ for the government and $49 \%$ for local authorities. After controlling other variables, severe impairment decreased the probability of a favourable trust score by 6-9 percentage points (depending on the institution) when compared to non-disabled people, while moderate impairment decreased it by 4-7 points.

Using a similar approach, the EQLS data indicated that severe impairment decreased voting probability by 8 percentage points in comparison to people without impairments but the negative association with moderate impairment was weak and not statistically robust. This, we suggest, may indicate the differentially negative impact of voting access barriers for people with more severe types of impairment, as suggested in the literature. Similarly, the EQLS and SILC data indicated that people with impairments were less likely to report participation in voluntary work, educational, social 
and political organizations, political parties and trades unions. Attendance at political meetings, trades union and party membership were also lower.

The SHARE data (sampling people aged over 50) indicated that those reporting impairments were more likely to be dissatisfied with their non-participation in social, political and other activities. This reiterated the concern that social or physical barriers as well as individual health limitations may be impeding full participation. This is further supported by data from the Flash Eurobarometer survey on 'Accessibility' in 2012, where one in five $(21.1 \%)$ respondents who reported that they or a member of their household had an impairment also reported difficulties voting in an election. These difficulties increased with severity of impairment $(28.4 \%$ severe; $14.2 \%$ moderate).

These findings at the European level show that there is a significant disability effect on political participation and that survey data offers a useful proxy to indicate this outcome. There is ample aggregate evidence of unequal outcomes to position disability rights as a significant socio-economic variable in political process and to suggest scope for the removal of barriers to full participation and equality. But what indications are there of the practical extent of such barriers beyond the legal structure and investments discussed earlier?

Accessibility outcome indicators were sought in relation to broadcast media and polling stations. Access to information is prerequisite to political participation but accessible forms of communication are needed to ensure participation for disabled people (notably for people with sensory or cognitive impairments). Promoting this kind of accessibility is one of the obligations that states have under Article 9 CRPD in the global governance framework. We looked for indicators of the accessibility of television and internetbased information relevant to political participation.

No directly comparable data was available on the provision of TV subtitles, audio description or sign language specific to electoral information but there was evidence that TV subtitling would be available in at least 13 out of 28 EU Member States for daily news programming from the main public TV broadcaster. A similar number of countries offered some sign language provision but coverage was limited. Evidence collected in $25 \mathrm{EU}$ countries in 2007-8 showed that even the best example (a Spanish public TV channel) provided sign language for only $15 \%$ of its national language programming and average provision by national public broadcasters across the EU was estimated at just $5 \%$ (Technosite et al., 2011).

Finally, we sought indicators of the extent of polling station accessibility for disabled voters. Where data was available estimates of the proportion of accessible polling stations in practice ranged between $2 \%$ and $50 \%$ (but not higher), suggesting that at least half might well exclude some voters. In 12 countries some official data had been collected by public authorities but it was often incomplete, either because it covered only certain cities or provinces or because it only considered accessibility for people with certain types of impairment (such as wheelchair users). In 13 out of the 28 EU Member States no source of information on polling station accessibility could be identified. This in itself indicates a cause for concern. Overall, populating comparative outcome indicators proved methodologically challenging but revealed important insights not only of unequal participation but also about awareness of accessibility for disabled people in political process. It highlighted the importance of including disability as a socioeconomic variable in political participation research.

\section{Conclusions}

The dynamics of political participation have received extensive research attention for more than half a century, with an early focus on electoral studies (e.g. Burdick and Brodbeck, 1959). This has revealed a range of factors influencing outcomes, such as political interest, group consciousness, voter resources and political recruitment via formal and informal networks (Rosenstone and Hansen, 1993; Verba et al., 1995). The concept of political participation has expanded (Huntington and Nelson, 1976) to include, for example, attending meetings, signing petitions or activism in political protests and new social movements (e.g. Li and Marsh, 2008; Parry and Moyser, 1992; Sabucedo and Arce, 1991; Stolle and Hooghe, 2011). The relationship between governments and citizens has also evolved through increased citizen engagement in public administration (Dyck and Lascher, 2009; Osborne and Gaebler, 1992), online political engagement (Gibson and Cantijoch, 2013; Hargittai and Shaw, 2013; Tang and Lee, 2013), and the politicization of consumer choices (Forno and Ceccarini, 2006; Micheletti, 2003; Stolle et al., 2005).

Well-known factors such as voter resources, voting accessibility and engagement can be usefully applied to interrogate the political participation of disabled people but disability equality raises unique factors too-notably in the legal denial of voting rights on grounds of mental capacity, the accessibility of political processes, and the political activism of the disabled people's movement. Yet, with the exception of some national election studies in the USA and some studies concerning specific sub-groups of disabled people, there is a notable absence of disability as a socio-economic variable in political participation research. Up to one quarter of the European electorate identify themselves as having some kind of impairment or long-term health condition that affects their daily activities (some 80 million people). Disabled people are a very significant constituency in European countries, growing with demographic ageing, of whose concerns any political party or candidate seeking election should be mindful.

This paper offers a first step in addressing this topic internationally, using examples of rights-based indicators developed in the EU and its 28 Member States. The rights in question have been established through transnational governance at global and European levels but they are implemented at national and local levels. Consequently, it is necessary to place national rights transgressions within an international context, in which both the European courts and the relevant UN Treaty Body now have a stake (i.e. the UN Committee on the Rights of Persons with Disabilities). By adapting a typology of structure, process and outcome indicators offered by the UN OHCHR the findings reveal deficiencies in fulfilling these rights as well as gaps in current knowledge that raise further questions for research.

There is a need to ensure freedom and privacy in voting and standing for public office. This is underlined in CRPD rights to equal recognition before the law and to the exercise of legal capacity (Article 12), to freedom of expression and opinion and access to information (Article 21), or respect for privacy (Article 22). While the Convention has been ratified by almost all EU Member States greater efforts are needed to ensure basic political rights for all. Diligence is needed to ensure voter registration for those most excluded, including people living in institutions, and national legislation depriving people of the right to vote on grounds of disability must be amended where it still exists.

To ensure that rights become a reality states need to raise the awareness of all stakeholders in the political process. Raising disability awareness in general is a CRPD obligation (Article 8) as is ensuring participation in cultural life, including the mass media (Article 30). More specifically, electoral authorities need to be better informed on disability equality, to monitor outcomes and to ensure that officials are briefed on reasonable adjustments and accessibility for disabled voters. 
The exercise of political rights is contingent upon equal access to political information and political activities. The EU has been active in regulating to improve accessibility in public transport and telecommunications equipment, and the availability of television subtitling has grown, but the provision of sign language and audio description is sparse and should be mandatory for TV election broadcasts and key debates. National political parties do not carry the same accessibility obligations as states but where they receive state funding their commitments to disability equality should be pre-requisite, as they are now for EU-funded parties.

There is a need to expand opportunities for disabled people to participate in public and political life more widely. Many disabled people have been marginalised from public life in ways that require politicians and campaigners to reach out to them. Creating meaningful engagement with disabled people in policy process is also a CRPD obligation, yet this has not been formalised in the political institutions of most EU Member States.

Some 25 years ago Oliver, in his seminal work on the Politics of Disablement (revised by Oliver and Barnes, 2012), concluded that:

...disabled people cannot look to either the welfare state or traditional political activities to effect considerable material and social improvements in the quality of their lives. The only hope, therefore, is that the disability movement will continue to grow in strength and consequently have a substantial impact on the politics of welfare provision (Oliver, 1990: 112)

Past research suggests that politically marginalised groups may be better engaged by speaking publicly to their concerns and by engaging with civil society organizations that represent their voices. A growing political awareness of disability rights is evident in the commitments made by the EU and its Member States to the global framework of the CRPD but focused action is still needed to put in place the pre-requisites for disabled people's political participation-rights, accessibility and representation.

\section{Acknowledgement}

This paper draws on data from collaborative research funded by the European Agency for Fundamental Rights and by the European Commission under the PROGRESS initiative (grant number JUST/ 2011/PROG/PR/01/D3). Mark Priestley is Scientific Director of the European Commission's Academic Network of European Disability experts (ANED) and Martha Stickings is Research Support Officer in the Equality and Citizens' Rights Department of the European Union Agency for Fundamental Rights (FRA). This article is written in a private capacity and the views expressed are strictly personal and cannot be attributed to either the European Commission or FRA.

\section{References}

Abberley, P., 1992. Counting us out: a discussion of the OPCS disability surveys. Disabil. Handicap Soc. 7 (2), 139-155.

Altman, B.M., Barnartt, S.N., 2006. International Views on Disability Measures: Moving Toward Comparative Measurement, Research in Social Science and Disability. Emerald Group Publishing Limited, Bingley.

Anderson, M.R., 2010. Community psychology, political efficacy, and trust. Polit. Psychol. 31 (1), 59-84.

Bandura, A., 1997. Self-efficacy: the Exercise of Control. Macmillan, London.

Bandura, A., 2000. Exercise of human agency through collective efficacy. Curr. Dir. Psychol. Sci. 9 (3), 75-78.

Baum, M., Espírito-Santo, A., 2007. In: Freire, A., et al. (Eds.), Exploring the Gender Gap in Portugal: Women's Political Participation, pp. 173-201.

Bell, D.M., McKay, C., Phillips, K.J., 2001. Overcoming the barriers to voting experienced by people with learning disabilities. Br. J. Learn. Disabil. 29 (4), 122-127. Bhabha, J., 1999. Belonging in Europe: citizenship and post-national rights. Int. Soc. Sci. J. 51 (159), 11-23.

Börsch-Supan, A., Brandt, M., Hunkler, C., Kneip, T., Korbmacher, J., Malter, F.,
Schaan, B., Stuck, S., Zuber, S., 2013a. Data resource profile: the Survey of Health, Ageing and Retirement in Europe (SHARE). Int. J. Epidemiol. dyt088.

Börsch-Supan, A., Brandt, M., Litwin, H., Weber, G., 2013b. Active Ageing and Solidarity Between Generations in Europe: First Results from SHARE After the Economic Crisis. Walter de Gruyter.

Brady, H.E., Verba, S., Schlozman, K.L., 1995. Beyond SES: a resource model of political participation. Am. Polit. Sci. Rev. 89 (02), 271-294.

Burdick, E., Brodbeck, A.J., 1959. American Voting Behavior. Free Press.

Caprara, G.V., Vecchione, M., Capanna, C., Mebane, M., 2009. Perceived political selfefficacy: theory, assessment, and applications. Eur. J. Soc. Psychol. 39 (6), 1002-1020.

Confederal Group of the European United Left/Nordic Green Left, 2013. Meeting of the Presidents of the Political Groups of the European Parliament with the European Disability Forum: Final Declaration, Brussels.

Dalton, R.J., Scarrow, S.E., Cain, B.E., 2004. Advanced democracies and the new politics. J. Democr. 15 (1), 124-138.

Driedger, D., 1989. The Last Civil Rights Movement: Disabled Peoples' International. Hurst \& Company, London.

Dyck, J.J., Lascher Jr., E.L., 2009. Direct democracy and political efficacy reconsidered. Polit. Behav. 31 (3), 401-427.

European Commission, 2010a. EU Citizenship Report 2010-dismantling the Obstacles to EU Citizens' Rights, Brussels.

European Commission, 2010b. European Disability Strategy 2010-2020: a Renewed Commitment to a Barrier-free Europe, Brussels.

European Commission, 2013. Flash Eurobarometer 345 (Accessibility). In: Social, T.P. (Ed.), Data File Version 1.0.0 ed. GESIS Data Archive. Cologne.

European Parliament, European Council, 2014. In: European Parliament, European Council (Eds.), Regulation of the European Parliament and of the Council on the Statute and Funding of European Political Parties and European Political Foundations. PE-CONS 62/14, Brussels.

European Social Survey, 2014. ESS-6 2012 Documentation Report, Edition 2.1. European Social Survey Data Archive, Bergen.

European Social Survey Round 6 Data, 2012. Data File Edition 2.1. Norwegian Social Science Data Services, Norway - Data Archive and Distributor of ESS Data.

European Union Agency for Fundamental Rights, 2010. The Right to Political Participation of Persons with Mental Health Problems and Persons with Intellectual Disabilities, Luxembourg.

European Union Agency for Fundamental Rights, 2011. FRA Symposium Report Using Indicators to Measure Fundamental Rights in the EU: Challenges and Solutions. Publications Office of the European Union, Luxembourg.

European Union Agency for Fundamental Rights, 2013. Legal Capacity of Persons with Intellectual Disabilities and Persons with Mental Health Problems. Publications Office of the European Union, Luxembourg.

European Union Agency for Fundamental Rights, 2014. Political Participation of Persons with Disabilities. Publications Office of the European Union, Luxeembourg.

Eurostat, 2010. EU-SILC Module 2006 on Social Participation: Assessment of the Implementation. Directorate F: Social and Information Society Statistics. Unit F3: Living Conditions and Social Protection, Luxembourg.

Fleischer, D.Z., Zames, F., 2001. The Disability Rights Movement: From Charity to Confrontation. Temple University Press.

Forno, F., Ceccarini, L., 2006. From the street to the shops: the rise of new forms of political actions in Italy. South Eur. Soc. Polit. 11 (2), 197-222.

Gallego, A., 2007. Unequal political participation in Europe. Int. J. Sociol. 37 (4), $10-25$.

GfK EU3C, 2014. 3rd European Quality of Life Survey: Technical Report the European Foundation for the Improvement of Living and Working Conditions, Dublin.

Gibson, R., Cantijoch, M., 2013. Conceptualizing and measuring participation in the age of the internet: is online political engagement really different to offline? J. Polit. 75 (03), 701-716.

Goodwin, M., Susar, D., Nietzio, A., Snaprud, M., Jensen, C.S., 2011. Global web accessibility analysis of national government portals and ministry web sites. J. Inf. Technol. Polit. 8 (1), 41-67.

Grammenos, S., 2013a. European Comparative Data on Europe 2020 and People with Disabilities. Academic Network of EuropeanDisability experts, Utrecht.

Grammenos, S., 2013b. European Comparative Data on People with Disabilities and Citizenship. Academic Network of European Disability experts, Utrecht.

Grönvik, L., 2009. Defining disability: effects of disability concepts on research outcomes. Int. J. Soc. Res. Methodol. 12 (1), 1-18.

Hargittai, E., Shaw, A., 2013. Digitally Savvy citizenship: the role of internet skills and engagement in young adults' political participation around the 2008 presidential election. J. Broadcast. Electron. Media 57 (2), 115-134.

Huntington, S.P., Nelson, J.M., 1976. No Easy Choice: Political Participation in Developing Countries. Harvard University Press, Cambridge.

Jennings, M.K., 1983. Gender roles and inequalities in political participation: results from an eight-nation study. West. Polit. Q. 364-385.

Karlawish, J.H., Bonnie, R.J., Appelbaum, P.S., Lyketsos, C., James, B., Knopman, D., Patusky, C., Kane, R.A., Karlan, P.S., 2004. Addressing the ethical, legal, and social issues raised by voting by persons with dementia. JAMA 292 (11), 1345-1350.

Kasfir, N., 1970. Explaining ethnic political participation. World Polit. 31.

Keeley, H., Redley, M., Holland, A., Clare, I., 2008. Participation in the 2005 general election by adults with intellectual disabilities. J. Intellect. Disabil. Res. 52 (3), $175-181$.

Lancee, B., Van de Werfhorst, H.G., 2012. Income inequality and participation: a comparison of 24 European countries. Soc. Sci. Res. 41 (5), 1166-1178. 
Landman, T., 2004. Measuring human rights: principle, practice and policy. Hum. Rights Q. 26 (4), 906-931.

Lawson, A., 2014. Access to and Accessibility of Citizenship and Political Participation of People with Disabilities in Europe Part II: Indicators of Accessible Voting and Political Participation. Academic Network of European Disability experts, Utrecht/Leeds.

Lawson, A., Priestley, M., 2009. Monitoring the Implementation of the UN Convention on the Rights of Persons with Disabilities in Europe: Principles for the Identification and Use of Indicators.

Lawson, A., Priestley, M., 2013. Potential, principle and pragmatism in concurrent multinational monitoring: disability rights in the European Union. Int. J. Hum. Rights 17 (7-8), 739-757.

Leighley, J.E., Vedlitz, A., 1999. Race, ethnicity, and political participation: competing models and contrasting explanations. J. Polit. 61 (04), 1092-1114.

Li, Y., Marsh, D., 2008. New forms of political participation: searching for expert citizens and everyday makers. Br. J. Polit. Sci. 38 (2), 247.

Madans, J.H., Loeb, M.E., Altman, B.M., 2011. Measuring disability and monitoring the UN Convention on the rights of persons with disabilities: the work of the Washington Group on Disability Statistics. BMC Public Health 11 (Suppl. 4), S4.

Malter, F., Börsch-Supan, A., 2013. SHARE Wave 4: Innovations \& Methodology. MEA, Max Planck Institute for Social Law and Social Policy, Munich.

Mattila, M., 2003. Why bother? Determinants of turnout in the European elections Elect. Stud. 22 (3), 449-468.

McNeese, T., 2013. Disability Rights Movement. ABDO Publishing Company.

Micheletti, M., 2003. Political Virtue and Shopping: Individuals, Consumerism, and Collective Action. Palgrave Macmillan.

Milbrath, L.W., 1965. Political Participation: How and Why Do People Get Involved in Politics? Rand McNally \& Company, Chicago.

Milbrath, L.W., 1981. Political Participation, the Handbook of Political Behavior Springer, pp. 197-240.

Morales, L., 1999. Political participation: exploring the gender gap in Spain. South Eur. Soc. Polit. 4 (2), 223-247.

O'sullivan, J.L., 2001. Voting and nursing home residents: a survey of practices and policies. J. Health Care L. Pol'y 4, 325.

Office of the High Commissioner for Human Rights, 2006. Report on Indicators for Monitoring Compliance with International Human Rights Instruments. United Nations, New York/Geneva.

Office of the High Commissioner for Human Rights, 2008. Report on indicators for promoting and monitoring the implementation of human rights (HRI/MC/2008/ 3). In: 20th Meeting of Chairpersons of the Human Rights Treaty Bodies, Geneva.

Office of the High Commissioner for Human Rights, 2012. Human Rights Indicators: a Guide to Measurement and Implementation, New York/Geneva.

Oliver, M., 1990. The Politics of Disablement: Critical Texts in Social Work and the Welfare State. Macmillan, London.

Oliver, M., Barnes, C., 2012. The New Politics of Disablement. Palgrave Macmillan.

Osborne, D., Gaebler, T., 1992. Reinventing Government: How the Entrepreneuria Spirit is Transforming Government. Reading Mass. Adison Wesley Public Comp.

Parry, G., Moyser, G., 1992. Political Participation and Democracy in Britain. Cambridge UP, Cambridge.

Pfeiffer, D., 1993. Overview of the disability movement: history, legislative record, and political implications. Policy Stud. J. 21 (4), 724-734.

Redley, M., 2008. Citizens with learning disabilities and the right to vote. Disabil. Soc. 23 (4), 375-384.

Rosenstone, S., Hansen, J.M., 1993. Mobilization, Participation and Democracy in America.
Ruedin, D., 2007. Testing Milbrath's 1965 framework of political participation: institutions and social capital. Contemp. Issues Ideas Soc. Sci. 3 (3).

Sabucedo, J., Arce, C., 1991. Types of political participation: a multidimensional analysis. Eur. J. Polit. Res. 20 (1), 93-102.

Schriner, K., Batavia, A.I., 2001. The Americans with disabilities act: does it secure the fundamental right to vote? Policy Stud. J. 29 (4), 663-673.

Schriner, K., Ochs, L.A., Shields, T.G., 1997. The last suffrage movement: voting rights for persons with cognitive and emotional disabilities. Publ. J. Fed. 27 (3), 75-96.

Schur, L. Adya, M. 2013. Sidelined or mainstreamed? Political participation and attitudes of people with disabilities in the United States. Soc. Sci. Q. 94 (3), 811-839.

Schur, L., Shields, T., Kruse, D., Schriner, K., 2002. Enabling democracy: disability and voter turnout. Polit. Res. Q. 55 (1), 167-190.

Schur, L.A., 1998. Disability and the psychology of political participation. J. Disabil. Policy Stud. 9 (2), 3-31.

Scotch, R.K., 1988. Politics and policy in the history of the disability rights movement. Milbank Q. 67, 380-400.

Shakespeare, T., 1993. Disabled people's self-organisation: a new social movement? Disabil. Handicap Soc. 8 (3), 249-264.

Shields, T.G., Schriner, K.F., Schriner, K., 1998a. The disability voice in American politics political participation of people with disabilities in the 1994 election. J. Disabil. Policy Stud. 9 (2), 33-52.

Shields, T.G., Schriner, K.F., Schriner, K., 1998b. Influences on the political participation of people with disabilities the role of individual and Elite Factors in 1984 and 1986. J. Disabil. Policy Stud. 9 (2), 77-91.

Stalford, H., Sax, H., Drywood, E., 2009. Developing Indicators for the Protection, Respect and Promotion of the Rights of the Child in the European Union, Summary Report. European Union Agency for Fundamental Rights, Vienna.

Stolle, D., Hooghe, M., 2011. Shifting inequalities: patterns of exclusion and inclusion in emerging forms of political participation. Eur. Soc. 13 (1), 119-142.

Stolle, D., Hooghe, M., Micheletti, M., 2005. Politics in the supermarket: political consumerism as a form of political participation. Int. Polit. Sci. Rev. 26 (3), $245-269$.

Tang, G., Lee, F.L., 2013. Facebook use and political participation the impact of exposure to shared political information, connections with public political actors, and network structural heterogeneity. Soc. Sci. Comput. Rev. 31 (6), $763-773$.

Technosite, NOVA, CNIPA, 2011. Monitoring eAccessibility in Europe: 2011 Annual Report. Technosite, Madrid.

TNS Opinion \& Social, 2013. European Union Citizenship.

Verba, S., Schlozman, K.L., Brady, H.E., 1995. Voice and Equality: Civic Voluntarism in American Politics. Harvard University Press.

Waddington, L., 2014. Access to and Accessibility of Citizenship and Political Participation of People with Disabilities in Europe Part I. Academic Network of European Disability experts, Utrecht/Leeds.

Waterstone, M., 2003. Constitutional and statutory voting rights for people with disabilities. Stan. L. Pol'y Rev. 14, 353.

Wrinkle, R.D., Stewart, J., Polinard, J., Meier, K.J., Arvizu, J.R., 1996. Ethnicity and nonelectoral political participation. Hispanic J. Behav. Sci. 18 (2), 142-153.

Yeich, S., Levine, R., 1994. Political efficacy: enhancing the construct and its relationship to mobilization of people. J. Community Psychol. 22 (3), 259-271.

Young, Iris M., 2002. Inclusion and Democracy. Oxford University Press, Oxford.

Zakaria, F., 2007. The Future of Freedom: Illiberal Democracy at Home and Abroad (Revised Edition). WW Norton \& company.

Zola, I.K., 1993. Disability statistics, what we count and what it tells us a personal and political analysis. J. Disabil. Policy Stud. 4 (2), 9-39. 